\title{
Effects of salinity and fertigation practice on cotton yield and ${ }^{15} \mathrm{~N}$ recovery
}

\author{
Zhenan Hou ${ }^{a}$, Weiping Chen ${ }^{\mathrm{b}, \mathrm{c}}$, Xiao $\mathrm{Li}^{\mathrm{a}}$, Lin Xiu ${ }^{\mathrm{a}}$, Laosheng Wu ${ }^{\mathrm{b}, *}$ \\ a Department of Resources and Environmental Sciences, Shihezi University, Shihezi, Xinjiang 832003, China \\ ${ }^{\mathrm{b}}$ Department of Environmental Sciences, University of California, Riverside, CA 92521, USA \\ ' State Key Lab of Urban and Regional Ecology, Research Center for Eco-Environmental Sciences, Chinese Academy of Sciences, Beijing 100085, China
}

\section{A R T I C L E I N F O}

\section{Article history:}

Received 20 January 2009

Accepted 20 April 2009

Available online 23 May 2009

\section{Keywords:}

Drip irrigation

Soil salinity

Fertigation strategy

${ }^{15} \mathrm{~N}$ recovery

Cotton

\begin{abstract}
A B S T R A C T
The purpose of optimal water and nutrient management is to maximize water and fertilizer use efficiency and crop production, and to minimize groundwater pollution. In this study, field experiments were conducted to investigate the effect of soil salinity and $\mathrm{N}$ fertigation strategy on plant growth, $\mathrm{N}$ uptake, as well as plant and soil ${ }^{15} \mathrm{~N}$ recovery. The experimental design was a $3 \times 3$ factorial with three soil salinity levels $\left(2.5,6.3\right.$, and $\left.10.8 \mathrm{dS} \mathrm{m}^{-1}\right)$ and three $\mathrm{N}$ fertigation strategies ( $\mathrm{N}$ applied at the beginning, end, and in the middle of an irrigation cycle). Seed cotton yield, dry matter, $\mathrm{N}$ uptake, and plant ${ }^{15} \mathrm{~N}$ recovery significantly increased as soil salinity level increased from 2.5 to $6.3 \mathrm{dS} \mathrm{m}^{-1}$, but they decreased markedly at higher soil salinity of $10.8 \mathrm{dS} \mathrm{m}^{-1}$. Soil ${ }^{15} \mathrm{~N}$ recovery was higher under soil salinity of $10.8 \mathrm{dS} \mathrm{m}^{-1}$ than those under soil salinity of $6.3 \mathrm{dS} \mathrm{m}^{-1}$, but was not significantly different from that under soil salinity of $2.5 \mathrm{dS} \mathrm{m}^{-1}$. The fertigation strategy that nitrogen applied at the beginning of an irrigation cycle had the highest seed cotton yield and plant ${ }^{15} \mathrm{~N}$ recovery, but showed higher potential loss of fertilizer $\mathrm{N}$ from the root zone. While the fertigation strategy of applying $\mathrm{N}$ at the end of an irrigation cycle tended to avoid potential $\mathrm{N}$ loss from the root zone, it had the lowest cotton yield and nitrogen use efficiency. Total ${ }^{15} \mathrm{~N}$ recovery was not significantly affected by soil salinity, fertigation strategy, and their interaction. These results suggest that applying nitrogen at the beginning of an irrigation cycle has an advantage on promoting yield and fertilizer use efficiency, therefore, is an agronomically efficient way to provide cotton with fertilizer $\mathrm{N}$ under the given production conditions. (c) 2009 Elsevier B.V. All rights reserved.
\end{abstract}

\section{Introduction}

Water scarcity and soil salinization are two main constraints for crop production in the arid and semiarid regions of the world. Judicious fertilizer and water management is essential in these regions in order to sustain crop production, soil and groundwater quality. Drip irrigation is considered to be the most efficient irrigation method, which can distribute water more uniformly, control the amount of water application more precisely, reduce evaporation and deep percolation, and minimize salinity effects (Sammis, 1980; Batchelor et al., 1996; Ayars et al., 1999; Karlberg and Frits, 2004). It is also the most suitable method for fertigation (Feigin et al., 1982; Sammis, 1980; Papadopoulos, 1985), which enables the application of soluble fertilizers and other chemicals along with irrigation water more uniformly and efficiently (Narda and Chawla, 2002).

For proper and efficient drip irrigation water management practices, it is imperative to understand the interactions between

\footnotetext{
* Corresponding author. Tel.: +1 951827 4664; fax: +1 9518275295 .

E-mail address: laosheng.wu@ucr.edu (L. Wu).
}

irrigation strategies, soil properties, root distribution patterns, and uptake of water and nutrients (Hopmans and Bristow, 2002; Gardenas et al., 2005). Some studies had investigated the effects of fertigation management on the spatial distribution and crop availability of supplied nitrogen (Somma et al., 1998; Mailhol et al., 2001; Li et al., 2004; Ajdary et al., 2007). Cote et al. (2003) analyzed the influences of fertigation strategy on solute distribution in a subsurface trickle irrigation system using HYDRUS-2D model. They demonstrated that fertigation at the beginning of the irrigation cycle might reduce nitrate leaching under specific conditions. $\mathrm{Li}$ et al. (2004) investigated the effects of fertigation strategies on nitrogen distribution in the soil from a surface point source. In order to avoid potential loss of nitrate from the root zone, they suggested that the flushing of the remaining fertilizer solution in drip pipelines should be as short as possible after fertilizer application is finished. Gardenas et al. (2005) and Hanson et al. (2006) simulated the distribution of soil nitrogen and nitrate leaching under five different fertigation strategies. They reported that under the surface drip irrigation, nitrate leaching was smallest when fertilizer was applied at the end of the irrigation cycle and largest when the fertilizer was applied at the beginning of the irrigation cycle. Ajdary et al. (2007) simulate the nitrogen leaching 
from various soils by varying emitter discharge rates and fertigation strategies based on a 2-year field experiment. They demonstrated that fertigation strategies, including fertigation in the beginning of irrigation, fertigation at the end of irrigation, and irrigation on daily basis, did not affect nitrogen leaching as much as commonly perceived.

Proper management of $\mathrm{N}$ fertilizer is especially important in saline soils where $\mathrm{N}$ application might reduce the adverse effects of salinity on plant growth and yield (Shen et al., 1994; Soliman et al., 1994; Grattan and Grieve, 1999; Albassam, 2001; Flores et al., 2001). In Xinjiang, China, a commonly used fertigation strategy is to start $\mathrm{N}$ injection when one-third of the total irrigation water during an irrigation event has been applied and to stop at $0.5 \mathrm{~h}$ before the irrigation cycle ends. But it is unclear if the current practice represents the best management practice in the region.

Xinjiang is the largest cotton (Gossipium hirsutum L.) production province in China, and cotton is a leading cash crop in the region. The planting area has been expanding rapidly since the 1990s after the introduction of drip irrigation, plastic mulching and high planting density to this area (Wang et al., 2004). The environmental conditions for cotton production in Xinjiang are similar to those in the San Joaquin Valley of California, United States, namely high evaporation, small amounts of precipitation during the growing period, and high level of soil salinity.

The main objective of this study is to evaluate the influences of soil salinity and $\mathrm{N}$ fertigation strategies on the cotton yield and $\mathrm{N}$ fertilizer use efficiency under field conditions of Xinjiang using ${ }^{15} \mathrm{~N}$-labelling technique as influenced by three fertigation strategies in combination with three levels of soil salinity.

\section{Materials and methods}

\subsection{Site description}

The field experiments were conducted at the agricultural experiment station of Shihezi University, located in Shihezi, Xinjiang in the northwestern China $\left(44^{\circ} 18^{\prime} \mathrm{N}, 86^{\circ} 02^{\prime} \mathrm{E}\right)$. The region is classified as a warm-temperate arid zone with continental climate. The mean annual temperature is $6.9^{\circ} \mathrm{C}$. July is the hottest month with a mean temperature of $26.1^{\circ} \mathrm{C}$. January is the coldest month with a mean temperature of $-18{ }^{\circ} \mathrm{C}$. The mean annual rainfall is $170 \mathrm{~mm}$, of which as much as $60 \%$ is received between April and August. The relative humidity during summer months varies from $30 \%$ to $50 \%$. Annual potential evaporation is about $1660 \mathrm{~mm}$ and the groundwater table is about $6 \mathrm{~m}$ from the surface. The soils in the study area are the alluvial-originated gray desert soils. The study site has a flat topography. Selected physical and chemical characteristics for the top 1.0-m soil profile are presented in Table 1.

\subsection{Field experiments}

Cotton (G. hirsutum L.cv. Xinluzao 13) was sown at the end of April, 2007. The growing season was from May to September. The experimental design was a $3 \times 3$ factorial with three soil salinity levels and three $\mathrm{N}$ fertigation strategies. Soil salinity was created by applying $\mathrm{NaCl}$ and $\mathrm{CaCl}_{2}(1: 1 \mathrm{w} / \mathrm{w})$ through the irrigation system to the soil from 2004 to 2006 . The average soil salinity levels $\left(E_{e}\right.$, electrical conductivity of a saturated-paste extract) were $2.5,6.3$, and $10.8 \mathrm{dS} \mathrm{m}^{-1}$, noted as S1 (control), S2, and S3, respectively. According to the $\mathrm{N}$ injection time in an irrigation cycle, the three $\mathrm{N}$ fertigation strategies were: (1) nitrogen applied at the beginning of the irrigation cycle $(\mathrm{N}-\mathrm{W}) ;(2)$ nitrogen applied at the end of the irrigation cycle (W-N); (3) nitrogen applied in the middle of the irrigation cycle $(\mathrm{W}-\mathrm{N}-\mathrm{W})$. The fertigation duration was $1 / 3$ of the total irrigation duration in an irrigation cycle.

The spatial distribution of the experimental plots followed a randomized block design. For each treatment, there were three replicates (main plots). In each main plot, there were two $1.2 \mathrm{~m} \times 25 \mathrm{~m}$ beds, with a $0.6-\mathrm{m}$ separation distance. Each bed had four plant rows and was covered with plastic film. Two irrigation drip tapes were installed under the plastic film in each bed. Cotton seeds were sown at 0.1 -m intervals in the row to yield a population of 222,000 plants ha ${ }^{-1}$. In each main plot, one ${ }^{15} \mathrm{~N}$ micro-plot $(0.6 \mathrm{~m} \times 0.8 \mathrm{~m})$ was randomly constructed to trace the fate of $\mathrm{N}$ fertilizer. There were two rows of plants in each ${ }^{15} \mathrm{~N}$ micro-plot. The ${ }^{15} \mathrm{~N}$ micro-plots were isolated with double layer of polythene sheet (thickness $0.5 \mathrm{~mm}$ ) to a depth of $1.0 \mathrm{~m}$ to reduce lateral flow of water and ${ }^{15} \mathrm{~N}$. The ${ }^{15} \mathrm{~N}$ micro-plots received ${ }^{15} \mathrm{~N}$ labelled urea ( $5 \%$ atom enrichment) while the main plots received unlabelled urea. The $\mathrm{N}$ application rate was $240 \mathrm{~kg} \mathrm{ha}^{-1}$ for both types of plots. Nitrogen fertilizer was applied through drip irrigation system in five split applications at 56, 66, 73, 83 and 95 days after planting (DAP), according to common field practices used by local farmers. To fully meet the nutrient requirement for the cottons, $105 \mathrm{~kg} \mathrm{P}_{2} \mathrm{O}_{5} \mathrm{ha}^{-1}$ and $60 \mathrm{~kg} \mathrm{~K}_{2} \mathrm{O} \mathrm{ha}^{-1}$ were also applied uniformly as base fertilizers.

Plots were drip irrigated with $30 \mathrm{~mm}$ water to improve germination and seedling establishment after sowing. The discharge rate of the emitters (pressure compensated) was $1.1 \mathrm{l} \mathrm{h}^{-1}$ and they were $0.4 \mathrm{~m}$ apart. During the cotton growing season, $375 \mathrm{~mm}$ water was applied through the drip irrigation system for all treatments. The drip irrigation was commenced towards early June and continued up to August. The irrigation interval was 7-15 days based on the recommendations for the non-saline soils of the area. The exact amount of water application was determined with water meter for each plot.

\subsection{Sampling and measurement methods}

Plant and soil samples were taken at boll opening stage (120 DAP) in each of the ${ }^{15} \mathrm{~N}$ micro-plots. All the plants were cut 0.5 -

Table 1

Selected soil properties of the experimental fields.

\begin{tabular}{|c|c|c|c|c|c|}
\hline \multirow[t]{2}{*}{ Parameters } & \multicolumn{5}{|c|}{ Soil depth (m) } \\
\hline & $0-0.2$ & $0.2-0.4$ & $0.4-0.6$ & $0.6-0.8$ & $0.8-1.0$ \\
\hline Sandy (\%) & 45.1 & 43.1 & 64.1 & 47.1 & 30.1 \\
\hline Silt (\%) & 36.7 & 40.5 & 22.6 & 31.4 & 42.2 \\
\hline Clay (\%) & 18.2 & 16.4 & 13.3 & 21.5 & 27.7 \\
\hline Bulk density $\left(\mathrm{Mg} \mathrm{m}^{-3}\right)$ & 1.27 & 1.40 & 1.33 & 1.40 & 1.45 \\
\hline $\mathrm{pH}\left(\mathrm{H}_{2} \mathrm{O}\right)$ & 7.50 & 7.55 & 7.76 & 7.88 & 7.80 \\
\hline Organic matter $\left(\mathrm{g} \mathrm{kg}^{-1}\right)$ & 15.7 & 11.3 & 6.42 & 4.34 & 3.31 \\
\hline Total nitrogen $\left(\mathrm{g} \mathrm{kg}^{-1}\right)$ & 1.02 & 0.81 & 0.54 & 0.35 & 0.24 \\
\hline Available phosphorus ( $\mathrm{mg} \mathrm{kg}^{-1}$ ) & 22.9 & 15.6 & 4.76 & 5.66 & 5.79 \\
\hline Available potassium $\left(\mathrm{mg} \mathrm{kg}^{-1}\right)$ & 272 & 232 & 152 & 152 & 168 \\
\hline
\end{tabular}


$1 \mathrm{~cm}$ above the soil surface using hand clippers and separated into leaves, stems, and fruits. Root samples were collected by passing the soil through a $0.16-\mathrm{mm}$ sieve with the aid of a water jet and removing non-root debris by hand. Each plant component was washed with distilled water, dried in an oven at $70{ }^{\circ} \mathrm{C}$ for $72 \mathrm{~h}$, and weighed. Subsamples were then taken and grounded to pass through a $1-\mathrm{mm}$ sieve for $\mathrm{N}$ analysis.

Soil samples were taken from six random positions in each micro-plot. The soil cores were divided into $0.1 \mathrm{~m}$ increments to a depth of $1.0 \mathrm{~m}$, and the six samples from the same micro-plot and depth were pooled and mixed. After air-drying, an aliquot of each pooled sample was ground with a porcelain mortar and pestle to pass a sieve with $75 \mu \mathrm{m}$ openings for $\mathrm{N}$ analysis.

In each main plot, seed cotton yield was measured by harvesting the cotton twice by hand, at 148 DAP when approximately $60 \%$ of the bolls opened and at 172 DAP when the experiment ended.

The EC of soil saturated-paste extraction was determined with a DDS-308A conductivity meter (Shanghai Precision \& Scientific Instrument Inc., Shanghai, China). Total $\mathrm{N}$ of soil and plant samples was analyzed using an Auto-Kjeldahl Unit (B-339, Buchi Labortechnik AG, Switzerland). For the determination of ${ }^{15} \mathrm{~N}$ concentrations, subsamples of the ground plant material and soil samples were analyzed at the Institute for Application of Atomic Energy, China Academy of Agricultural Science (Beijing, China) using a mass spectrometer (ANCA-SL, Europe Scientific, Crewe, UK).

\subsection{Data analysis}

The plant ${ }^{15} \mathrm{~N}$ recovery was calculated based on the following equation (Powell et al., 2005):

Plant ${ }^{15} \mathrm{~N}$ recovery $\%=\frac{P(c-d)}{f(a-b)} \times 100$

where $P=$ total cotton $\mathrm{N}$ in micro-plot $\left(\mathrm{g} \mathrm{plot}^{-1}\right), f=$ total applied fertilizer $\mathrm{N}$ in micro-plot $\left(\mathrm{g}\right.$ plot $^{-1}$ ), $a=$ at. $\%{ }^{15} \mathrm{~N}$ of applied fertilizer, $b=$ at. $\%{ }^{15} \mathrm{~N}$ in unlabelled fertilizer, $c=$ at. $\%{ }^{15} \mathrm{~N}$ of fertilized cotton, $d=$ at. $\%{ }^{15} \mathrm{~N}$ of cotton grown in unlabelled soil.

The soil ${ }^{15} \mathrm{~N}$ recovery was calculated by (Powell et al., 2005):

Soil ${ }^{15} \mathrm{~N}$ recovery $\%=\frac{Q(e-g)}{f(a-b)} \times 100$

where $Q=$ total soil $\mathrm{N}$ in micro-plot $\left(\mathrm{g} \mathrm{plot}^{-1}\right), e=$ at.\% ${ }^{15} \mathrm{~N}$ of total soil $\mathrm{N}$ in micro-plot, $g=$ at.\% ${ }^{15} \mathrm{~N}$ in unlabelled soil, and the other terms are the same as above.

Total fertilizer ${ }^{15} \mathrm{~N}$ recovery was calculated as the sum of recoveries in soil and crop components as following (Powell et al., 2005):

Total ${ }^{15} \mathrm{~N}$ recovery $\%=$ Plant ${ }^{15} \mathrm{~N}$ recovery $\%$

$$
+ \text { Soil }{ }^{15} \mathrm{~N} \text { recovery } \%
$$

The data were analyzed using SPSS statistical program (v. 11.0, SPSS Inc., 1996) with a two-way ANOVA at a significance level of 0.05 , with soil salinity and fertigation strategy as the independent variables. A Duncan's multiple range test was conducted to determine if significant $(P<0.05)$ differences exist under different soil salinity or fertigation strategy treatments.

\section{Results and discussion}

\subsection{Seed cotton yield}

The effects of soil salinity and fertigation strategy on seed cotton yield were summarized in Fig. 1. The seed cotton yield was significantly affected by soil salinity. On average, seed cotton yield

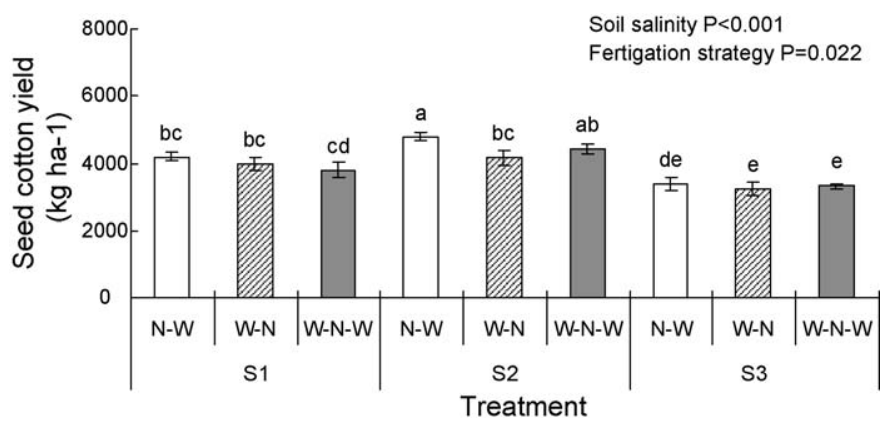

Fig. 1. Effects of soil salinity and fertigation strategy on seed cotton yield of cotton. Bars represent mean \pm S.E. $(n=3)$. Different letters indicate significant differences at $P<0.05$ (Duncan's test).

under S2 treatments was $12 \%$ and 35\% higher than that under S1 and S3 treatments, respectively. Compared to control, cotton growth and seed cotton yield were promoted under the soil salinity level of $6.3 \mathrm{dS} \mathrm{m} \mathrm{m}^{-1}$. The growth promoting effect of proper soil salinity has been reported by many researchers for various cotton cultivars, and it was attributed to the high salt tolerance of cotton and its corresponding pattern of nutrient and water uptake (El-Gharib and Kadry, 1983; Jafria and Ahmad, 1994; Pessarakli, 1995; Gorham and Bridges, 1995; Leidi and Saiz, 1997; Qdir and Shams, 1997; Ashraf, 2002). However, cotton growth can be inhibited as soil salinity further increases (e.g., S3 in this study) through osmotic stress, nutritional imbalance, and specific ion toxicity (Alam, 1994; Jacoby, 1994).

The seed cotton yield was also significantly affected by the fertigation strategy. The highest seed cotton yield was found under the $\mathrm{N}-\mathrm{W}$ treatments, which was, on average, $7 \%$ and $9 \%$ higher than that under the $\mathrm{W}-\mathrm{N}$ and $\mathrm{W}-\mathrm{N}-\mathrm{W}$ treatments, respectively. There was no significant difference of the seed cotton yield between the $\mathrm{W}-\mathrm{N}$ and $\mathrm{W}-\mathrm{N}-\mathrm{W}$ treatments. Effect of interaction between soil salinity and fertigation strategy on the seed cotton yield was not significant either. The effect of fertigation strategy on seed cotton yield was closely related to the nitrogen fertilizer use efficiency. At the same soil salinity, the plant ${ }^{15} \mathrm{~N}$ recovery was found significantly higher under the $\mathrm{N}-\mathrm{W}$ fertigation treatments than those under the other two fertigation strategies (see the following section for details).

\subsection{Dry matter mass and nitrogen uptake}

The effects of salinity and fertigation strategy on dry mass of cotton plant parts (leaves, stems, fruits and roots) are summarized in Table 2. The dry mass of different cotton plant parts were all significantly affected by the soil salinity levels. The dry mass of cotton plant parts under S2 treatments was significantly greater than under the other two soil salinity treatments. Compared to the control treatments (S1), the total dry mass under S2 treatments was increased by $23 \%$, while total dry mass under S3 treatments was reduced by $13 \%$.

Effect of fertigation strategy on dry mass of cotton plant parts was quite limited except for the fruit dry mass. Fruit dry mass under the $\mathrm{N}-\mathrm{W}$ and $\mathrm{W}-\mathrm{N}$ treatments was significantly higher than that under the $\mathrm{W}-\mathrm{N}-\mathrm{W}$ treatment. As a result, the total dry masses under the $\mathrm{N}$ W and W-N treatments were at the same level and were significantly higher than that under the $\mathrm{W}-\mathrm{N}-\mathrm{W}$ treatment. Overall, the effect of soil salinity on dry mass of cotton was much pronounced more than the fertigation strategy. There was no interaction effect between salinity and fertigation strategy on cotton dry mass.

The $\mathrm{N}$ uptake under different soil salinity and fertigation strategy treatments are summarized in Table 3. Cotton $\mathrm{N}$ uptake was significantly affected by soil salinity, but not by the fertigation 
Table 2

Effects of soil salinity and fertigation strategy on dry mass of cotton plant.

\begin{tabular}{|c|c|c|c|c|c|}
\hline \multirow[t]{2}{*}{ Treatment } & \multicolumn{5}{|c|}{ Dry mass $\left(\mathrm{g} \mathrm{plot}^{-1}\right)^{*}$} \\
\hline & Leaf & Stem & Fruit & Root & Total \\
\hline \multicolumn{6}{|l|}{ Soil salinity } \\
\hline $\mathrm{S} 1$ & $83 \pm 3 b$ & $108 \pm 4 b$ & $283 \pm 13 b$ & $40 \pm 2 b$ & $514 \pm 14 b$ \\
\hline $\mathrm{S} 2$ & $118 \pm 5 a$ & $144 \pm 11 \mathrm{a}$ & $322 \pm 15 a$ & $49 \pm 1 a$ & $633 \pm 20 a$ \\
\hline S3 & $88 \pm 7 b$ & $92 \pm 3 b$ & $246 \pm 5 c$ & $32 \pm 1 c$ & $449 \pm 7 c$ \\
\hline \multicolumn{6}{|l|}{ Fertigation strategy } \\
\hline $\mathrm{N}-\mathrm{W}$ & $89 \pm 10 b$ & $112 \pm 9 a$ & $304 \pm 18 a$ & $40 \pm 3 a$ & $544 \pm 33 a$ \\
\hline $\mathrm{W}-\mathrm{N}$ & $102 \pm 9 a$ & $118 \pm 13 a$ & $286 \pm 15 a b$ & $42 \pm 3 a$ & $549 \pm 35 a$ \\
\hline W-N-W & $88 \pm 6 b$ & $114 \pm 10 a$ & $262 \pm 11 b$ & $39 \pm 2 a$ & $503 \pm 25 b$ \\
\hline \multicolumn{6}{|l|}{ Analysis of variance ( $P$ values) } \\
\hline Soil salinity & $<0.001$ & $<0.001$ & $<0.001$ & $<0.001$ & $<0.001$ \\
\hline Fertigation strategy & 0.057 & 0.784 & 0.028 & 0.121 & 0.030 \\
\hline Salinity $\times$ fertigation strategy & 0.268 & 0.368 & 0.661 & 0.196 & 0.328 \\
\hline
\end{tabular}

Different letters in the same column indicate significant differences at $P<0.05$ (Duncan's test) among different soil salinity or fertigation strategy treatments.

Values are means \pm S.E. $(n=9)$.

Table 3

Effects of soil salinity and fertigation strategy on cotton $\mathrm{N}$ uptake.

\begin{tabular}{|c|c|c|c|c|c|}
\hline \multirow[t]{2}{*}{ Treatment } & \multicolumn{5}{|c|}{$\mathrm{N}$ content $\left(\mathrm{g} \mathrm{plot}^{-1}\right)^{*}$} \\
\hline & Leaf & Stem & Fruit & Root & Total \\
\hline \multicolumn{6}{|l|}{ Soil salinity } \\
\hline $\mathrm{S} 1$ & $2.15 \pm 0.09 b$ & $1.26 \pm 0.08 a$ & $6.67 \pm 0.24 b$ & $0.3 \pm 0.02 a$ & $10.4 \pm 0.28 b$ \\
\hline $\mathrm{S} 2$ & $2.91 \pm 0.15 a$ & $1.32 \pm 0.11 \mathrm{a}$ & $7.37 \pm 0.34 a$ & $0.37 \pm 0.02 a$ & $12.0 \pm 0.38 a$ \\
\hline S3 & $2.10 \pm 0.18 b$ & $1.05 \pm 0.03 b$ & $5.92 \pm 0.15 c$ & $0.28 \pm 0.01 b$ & $9.3 \pm 0.23 c$ \\
\hline \multicolumn{6}{|l|}{ Fertigation strategy } \\
\hline $\mathrm{N}-\mathrm{W}$ & $2.27 \pm 0.20 \mathrm{a}$ & $1.33 \pm 0.07 a$ & $6.93 \pm 0.34 a$ & $0.34 \pm 0.03 a$ & $10.8 \pm 0.51 a$ \\
\hline W-N & $2.31 \pm 0.19 a$ & $1.21 \pm 0.05 \mathrm{ab}$ & $6.73 \pm 0.39 a$ & $0.32 \pm 0.02 \mathrm{a}$ & $10.7 \pm 0.54 a$ \\
\hline W-N-W & $2.58 \pm 0.20 a$ & $1.08 \pm 0.11 b$ & $6.31 \pm 0.23 a$ & $0.31 \pm 0.01 a$ & $10.3 \pm 0.43 a$ \\
\hline \multicolumn{6}{|l|}{ Analysis of variance ( $P$ values) } \\
\hline Soil salinity & 0.001 & 0.032 & 0.001 & 0.001 & $<0.001$ \\
\hline Fertigation strategy & 0.267 & 0.066 & 0.184 & 0.273 & 0.459 \\
\hline Salinity $\times$ fertigation strategy & 0.743 & 0.631 & 0.409 & 0.007 & 0.700 \\
\hline
\end{tabular}

Different letters in the same column indicate significant differences at $P<0.05$ (Duncan's test) among different soil salinity or fertigation strategy treatments.

Values are means \pm S.E. $(n=9)$.

strategy. Interaction effect on $\mathrm{N}$ content of cotton root was observed. The total N uptake under S2 treatment was the highest, while the lowest total $\mathrm{N}$ uptake was found under $\mathrm{S} 3$ treatment. The trends were in consistence with those for seed cotton yield and dry mass.

\subsection{Plant ${ }^{15} \mathrm{~N}$ recovery}

The effects of soil salinity and fertigation strategy on plant ${ }^{15} \mathrm{~N}$ recovery were summarized in Table 4 . The leaf ${ }^{15} \mathrm{~N}$ recovery under various treatments ranged from $8.9 \%$ to $10.4 \%$ and was not significantly affected by the soil salinity and fertigation strategy. The stem ${ }^{15} \mathrm{~N}$ recovery under various treatments ranged from $2.9 \%$ to $3.9 \%$ and was only affected by the fertigation strategy. The stem ${ }^{15} \mathrm{~N}$ recovery under the $\mathrm{W}-\mathrm{N}$ treatment was significantly lower than that under the other two fertigation treatments. Both the fruit ${ }^{15} \mathrm{~N}$ recovery and root ${ }^{15} \mathrm{~N}$ recovery were significantly affected by the soil salinity and fertigation strategy. Fruit and root ${ }^{15} \mathrm{~N}$ recoveries under S2 treatment were $13 \%$ and $20 \%$, respectively, higher than that under S1 treatment; and 22\% and 31\%, respectively, higher than that under $\mathrm{S} 3$ treatment. Higher fruit and root ${ }^{15} \mathrm{~N}$ recoveries were found under the $\mathrm{N}-\mathrm{W}$ treatment, but there was no significant difference between the $\mathrm{W}-\mathrm{N}$ and $\mathrm{W}-\mathrm{N}-\mathrm{W}$ treatments. Given that the root ${ }^{15} \mathrm{~N}$ recovery (ranged from $0.65 \%$ to $0.96 \%$ ) was much less than the fruit ${ }^{15} \mathrm{~N}$ recovery (ranged from $22.4 \%$ to $27.4 \%$ ), it is concluded that the effects of soil salinity and fertigation strategy on plant ${ }^{15} \mathrm{~N}$ recovery were dominated by the fruit $\mathrm{N}$ uptake.
The total plant ${ }^{15} \mathrm{~N}$ recovery was significantly affected by soil salinity and fertigation strategy. The averaged cotton ${ }^{15} \mathrm{~N}$ recovery under S2 treatment was $42.4 \%$ and was significantly higher than that under S1 and S3 treatments (37.9\% and 35.5\%, respectively). The average cotton ${ }^{15} \mathrm{~N}$ recovery under the $\mathrm{N}-\mathrm{W}$ treatment was $12 \%$ and $20 \%$ higher than that under the $\mathrm{W}-\mathrm{N}$ and $\mathrm{W}-\mathrm{N}-\mathrm{W}$ treatments, respectively. There was no soil salinity and fertigation strategy interaction effect on the plant ${ }^{15} \mathrm{~N}$ recovery.

The cotton ${ }^{15} \mathrm{~N}$ recovery ranged from $28 \%$ to $49 \%$ with an average of $38 \%$ for different treatments. These values are similar to those reported by Rochester et al. (1994) for cotton. Chua et al. (2003) reported that plant ${ }^{15} \mathrm{~N}$ recoveries ranged from $19 \%$ to $38 \%$ for drip irrigated cotton during a 3-year study in three sites of western United States. Torbert and Reeves (1994) and Karlen et al. (1996) examined the fate of ${ }^{15} \mathrm{~N}$-labelled $\mathrm{NH}_{4} \mathrm{NO}_{3}$ applied to cotton in southeastern United States and reported that plant ${ }^{15} \mathrm{~N}$ recovery ranged from $25 \%$ to $35 \%$, while $40-60 \%$ of the applied ${ }^{15} \mathrm{~N}$ was lost from the plant-soil system. Fritschi et al. (2004) investigated the fate of ${ }^{15} \mathrm{~N}$-labelled urea applied to cotton grown in California and reported plant ${ }^{15} \mathrm{~N}$ recovery averaged $49 \%$ in a Panoche clay loam and $43 \%$ in a Wasco sandy loam.

\subsection{Soil ${ }^{15} N$ recovery}

Soil ${ }^{15} \mathrm{~N}$ recovery at different depths was measured at cotton boll opening stage. The results are summarized in Table 5 . In general, the soil ${ }^{15} \mathrm{~N}$ recovery decreased with depth and over $60 \%$ of 
Table 4

Effects of soil salinity and fertigation strategy on plant ${ }^{15} \mathrm{~N}$ recovery.

\begin{tabular}{|c|c|c|c|c|c|}
\hline \multirow[t]{2}{*}{ Treatment } & \multicolumn{5}{|c|}{ Plant ${ }^{15} \mathrm{~N}$ recovery $(\%)^{*}$} \\
\hline & Leaf & Stem & Fruit & Root & Total \\
\hline \multicolumn{6}{|l|}{ Soil salinity } \\
\hline S1 & $9.0 \pm 0.5 a$ & $3.9 \pm 0.2 \mathrm{a}$ & $24.3 \pm 1.6 b$ & $0.74 \pm 0.05 b$ & $37.9 \pm 2.0 \mathrm{~b}$ \\
\hline $\mathrm{S} 2$ & $10.4 \pm 1.0 \mathrm{a}$ & $3.6 \pm 0.4 \mathrm{ab}$ & $27.4 \pm 0.9 a$ & $0.89 \pm 0.13 a$ & $42.4 \pm 2.1 \mathrm{a}$ \\
\hline S3 & $9.2 \pm 0.7 a$ & $3.2 \pm 0.1 b$ & $22.4 \pm 0.6 b$ & $0.68 \pm 0.04 b$ & $35.5 \pm 0.9 b$ \\
\hline \multicolumn{6}{|l|}{ Fertigation strategy } \\
\hline $\mathrm{N}-\mathrm{W}$ & $10.4 \pm 0.9 a$ & $3.9 \pm 0.3 a$ & $27.2 \pm 1.4 a$ & $0.96 \pm 0.11 a$ & $42.5 \pm 2.4 a$ \\
\hline $\mathrm{W}-\mathrm{N}$ & $8.9 \pm 0.7 a$ & $2.9 \pm 0.1 b$ & $23.8 \pm 1.1 b$ & $0.65 \pm 0.05 b$ & $37.8 \pm 1.2 b$ \\
\hline W-N-W & $9.4 \pm 0.6 a$ & $3.9 \pm 0.2 \mathrm{a}$ & $23.1 \pm 1.0 \mathrm{~b}$ & $0.70 \pm 0.03 b$ & $35.5 \pm 1.4 b$ \\
\hline \multicolumn{6}{|l|}{ Analysis of variance ( $P$ values) } \\
\hline Soil salinity & 0.210 & 0.102 & 0.001 & 0.001 & 0.003 \\
\hline Fertigation strategy & 0.207 & 0.003 & 0.006 & $<0.001$ & 0.002 \\
\hline Salinity $\times$ fertigation strategy & 0.390 & 0.512 & 0.124 & $<0.001$ & 0.084 \\
\hline
\end{tabular}

Different letters in the same column indicate significant differences at $P<0.05$ (Duncan's test) among different soil salinity or fertigation strategy treatments.

Values are means \pm S.E. $(n=9)$.

total soil ${ }^{15} \mathrm{~N}$ was in the top $0.3-\mathrm{m}$ soil profile. The soil ${ }^{15} \mathrm{~N}$ recovery at different depths was significantly affected by soil salinity and fertigation strategy. In the top $0.3-\mathrm{m}$ soil profile, the soil ${ }^{15} \mathrm{~N}$ recovery under S2 treatment was significantly lower than that under S1 and $\mathrm{S} 3$ treatments, while the soil ${ }^{15} \mathrm{~N}$ recovery in the middle soil layer (0.3-0.6 m) under S1 treatment was significantly lower than that under S2 and S3 treatments. The soil ${ }^{15} \mathrm{~N}$ recovery in the bottom soil layer $(0.6-1.0 \mathrm{~m}$ ) decreased from $2.7 \%$ to $2.4 \%$, and to $1.8 \%$, as soil salinity level increased from $2.5 \mathrm{dS} \mathrm{m}^{-1}$ (S1 treatment) to $6.3 \mathrm{dS} \mathrm{m}^{-1}$ (S2 treatment), and to $10.8 \mathrm{dS} \mathrm{m}^{-1}$ (S3 treatment), respectively. Overall, the soil ${ }^{15} \mathrm{~N}$ recovery under different soil salinity treatments followed a decreasing order of S3 (16.6\%) > S1 $(15.2 \%)>$ S2 (13.8\%). The total soil ${ }^{15} \mathrm{~N}$ recovery under S1 and S3 treatments was significantly higher than under S2 treatment.

Soil ${ }^{15} \mathrm{~N}$ recovery at different depths was also significantly affected by the fertigation strategies. In the top $0.3-\mathrm{m}$ soil profile, the $\mathrm{W}-\mathrm{N}$ treatment had the highest soil ${ }^{15} \mathrm{~N}$ recovery and on average, it was $23 \%$ and $65 \%$ higher than that under the $\mathrm{W}-\mathrm{N}-\mathrm{W}$ and $\mathrm{N}-\mathrm{W}$ treatments, respectively. The soil ${ }^{15} \mathrm{~N}$ recovery in the middle soil profile $(0.3-0.6 \mathrm{~m})$ under different fertigation strategy treatments followed a decreasing order of $\mathrm{W}-\mathrm{N}>\mathrm{N}-\mathrm{W}>\mathrm{W}-\mathrm{N}-\mathrm{W}$. The lowest soil ${ }^{15} \mathrm{~N}$ recovery in the bottom soil layer $(0.6-1.0 \mathrm{~m})$ was found under the $\mathrm{W}-\mathrm{N}$ fertigation treatment, while the highest was found under the $\mathrm{N}-\mathrm{W}$ treatment. The average total soil ${ }^{15} \mathrm{~N}$ recovery in the $1.0-\mathrm{m}$ soil profile under the $\mathrm{W}-\mathrm{N}$ treatment was $25 \%$ and $31 \%$ higher than that under the $\mathrm{W}-\mathrm{N}-\mathrm{W}$ and $\mathrm{N}-\mathrm{W}$ treatments, respectively. These results agreed with those observed by Hou et al. (2007) that a significantly higher ${ }^{15} \mathrm{~N}$ recovery in the soil was found under the $\mathrm{W}-\mathrm{N}$ fertigation treatment than those under the $\mathrm{W}-\mathrm{N}-\mathrm{W}$ and $\mathrm{N}-\mathrm{W}$ fertigation treatments.

The total soil ${ }^{15} \mathrm{~N}$ recovery in the $1.0-\mathrm{m}$ soil profile ranged from $12 \%$ to $21 \%$. These numbers are consistent with the $12-35 \%$ of soil ${ }^{15} \mathrm{~N}$ recovery reported by others in soils planted with cotton (Freney et al., 1993; Rochester et al., 1993, 1994; Torbert and Reeves, 1994; Karlen et al., 1996; Allen et al., 2004). Compared with the $\mathrm{W}-\mathrm{N}-\mathrm{W}$ and $\mathrm{N}-\mathrm{W}$ treatments, more fertilizer $\mathrm{N}$ tended to be remained in the top soil layers under the $\mathrm{W}-\mathrm{N}$ treatment. The soil ${ }^{15} \mathrm{~N}$ recovery in the top $0.6-\mathrm{m}$ soil profile under different fertigation strategy treatments followed a decreasing order of W-N $(16.9 \%)>\mathrm{W}-\mathrm{N}-\mathrm{W}(11.9 \%)>\mathrm{N}-\mathrm{W}(10.0 \%)$. Conversely, more soil ${ }^{15} \mathrm{~N}$ was retained in the bottom soil layers $(0.6-1.0 \mathrm{~m})$ under the $\mathrm{N}$ $\mathrm{W}$ treatment than under the other two fertigation treatments. The average soil ${ }^{15} \mathrm{~N}$ recovery in the bottom soil layers under the $\mathrm{N}-\mathrm{W}$ treatment was $46 \%$ and $218 \%$ higher than those under the $\mathrm{W}-\mathrm{N}-\mathrm{W}$ and $\mathrm{W}-\mathrm{N}$ treatments, respectively. The result suggests that the $\mathrm{N}-$ $\mathrm{W}$ fertigation treatment (nitrogen applied at the beginning of the irrigation cycle) tends to move the applied $\mathrm{N}$ fertilizer to a deeper depth than the $\mathrm{W}-\mathrm{N}$ fertigation treatment (nitrogen applied at the end of the irrigation cycle), and the later practice (W-N treatment) can effectively reduce the fertilizer $\mathrm{N}$ leaching potential in the root zone. The results agreed with those reported by Gardenas et al. (2005) and Hanson et al. (2006) that the largest nitrate leaching losses occurred most often when fertigation was carried out at the beginning of an irrigation cycle, and the potential of nitrate

Table 5

Effects of soil salinity and fertigation strategy on soil ${ }^{15} \mathrm{~N}$ recovery at different depths.

\begin{tabular}{|c|c|c|c|c|}
\hline \multirow[t]{2}{*}{ Treatment } & \multicolumn{4}{|c|}{ Soil ${ }^{15} \mathrm{~N}$ recovery $(\%)^{*}$} \\
\hline & $0-0.3 \mathrm{~m}$ & $0.3-0.6 \mathrm{~m}$ & $0.6-1.0 \mathrm{~m}$ & $0-1.0 \mathrm{~m}$ \\
\hline \multicolumn{5}{|l|}{ Soil salinity } \\
\hline $\mathrm{S} 1$ & $10.5 \pm 0.8 a$ & $2.0 \pm 0.3 b$ & $2.7 \pm 0.5 a$ & $15.2 \pm 0.7 a b$ \\
\hline S2 & $8.7 \pm 0.9 b$ & $2.8 \pm 0.4 a$ & $2.4 \pm 0.4 b$ & $13.8 \pm 0.9 b$ \\
\hline S3 & $11.5 \pm 0.9 a$ & $3.2 \pm 0.5 a$ & $1.8 \pm 0.3 c$ & $16.6 \pm 1.1 \mathrm{a}$ \\
\hline \multicolumn{5}{|l|}{ Fertigation strategy } \\
\hline $\mathrm{N}-\mathrm{W}$ & $7.7 \pm 0.7 c$ & $2.3 \pm 0.3 b$ & $3.5 \pm 0.2 \mathrm{a}$ & $13.6 \pm 0.8 b$ \\
\hline W-N & $12.7 \pm 0.7 a$ & $4.2 \pm 0.3 a$ & $1.1 \pm 0.1 c$ & $17.8 \pm 0.8 a$ \\
\hline W-N-W & $10.3 \pm 0.5 b$ & $1.6 \pm 0.1 c$ & $2.4 \pm 0.3 b$ & $14.2 \pm 0.6 b$ \\
\hline \multicolumn{5}{|l|}{ Analysis of variance ( $P$ values) } \\
\hline Soil salinity & $<0.001$ & $<0.001$ & $<0.001$ & 0.016 \\
\hline Fertigation strategy & $<0.001$ & $<0.001$ & $<0.001$ & $<0.001$ \\
\hline Salinity $\times$ fertigation strategy & 0.418 & $<0.001$ & 0.001 & 0.440 \\
\hline
\end{tabular}

Different letters in the same column indicate significant differences at $P<0.05$ (Duncan's test) among different soil salinity or fertigation strategy treatments.

Values are means \pm S.E. $(n=9)$. 


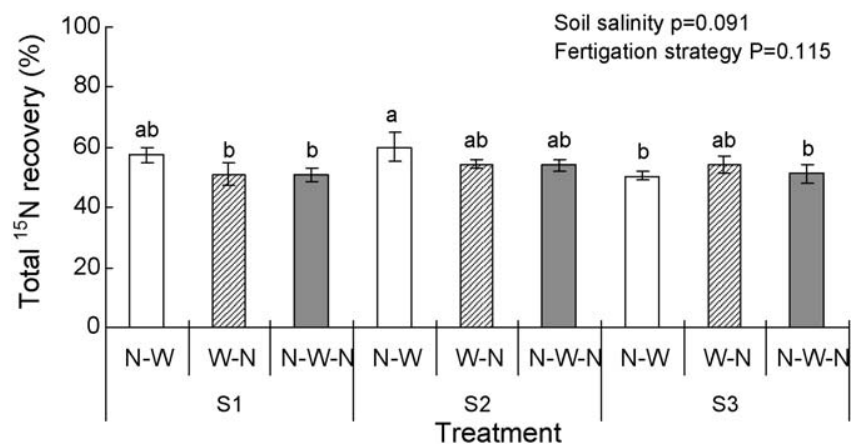

Fig. 2. Effects of soil salinity and fertigation strategy on the total ${ }^{15} \mathrm{~N}$ recovery in crop-soil system. Bars represent mean \pm S.E. $(n=3)$. Different letters indicate significant differences at $P<0.05$ (Duncan's test).

leaching in micro-irrigation systems was reduced when the fertigation was applied for a short time at the end of an irrigation cycle.

\subsection{Total ${ }^{15} \mathrm{~N}$ recovery}

The effects of soil salinity, $\mathrm{N}$ fertigation strategy, and their interaction on the total ${ }^{15} \mathrm{~N}$ recovery were insignificant (Fig. 2 ). The total ${ }^{15} \mathrm{~N}$ recovery under different treatments ranged from $46 \%$ to $66 \%$ with an average of $54 \%$. These values were within the range of total recovery of ${ }^{15} \mathrm{~N}$ in plants and soils reported by other studies for irrigated cotton (Freney et al., 1993; Rochester et al., 1994; Torbert and Reeves, 1994; Karlen et al., 1996), but were smaller than those reported by Chua et al. (2003) and Fritschi et al. (2004). The result showed that on average, more than $40 \%$ of the applied $\mathrm{N}$ was unaccounted from the soil-plant system during the growing season. These losses have been attributed to the combined effects of volatilization, denitrification, and leaching, while these factors were usually not independently measured (Raun and Johnson, 1999).

In this study, ${ }^{15} \mathrm{~N}$ was applied with irrigation water and the soil was covered with plastic film, therefore, ${ }^{15} \mathrm{NH}_{3}$ volatilization from soil should be quite limited. Freney et al. (1985) found that most of the applied $\mathrm{N}$ from a urea solution was leached out of the rootzone with the irrigation water and less than $2 \%$ of the applied N was lost through volatilization. Ajdary et al. (2007) found that the effect of soil type on nitrogen leaching was more pronounced than that by the emitter discharge rates. They also concluded that fertigation strategies did not affect the nitrogen leaching as commonly perceived. The model simulation results from Hanson et al. (2006) showed nitrogen leaching percentage ranged from $2.6 \%$ to $6.8 \%$ for different fertigation strategies. Their results suggested that the impact of fertigation strategy on nitrate leaching was limited and nitrate leaching was not very significant under drip irrigation.

Denitrification in soil wet zones therefore appears to be the highest possibility as a loss pathway (Thompson et al., 2000; Chua et al., 2003). This has been reported for irrigated cotton fields in Australia, where $43-63 \%$ loss of the applied $\mathrm{N}$ fertilizer was attributed mainly to denitrification (Freney et al., 1993; Chen et al., 1994).

\subsection{Management options}

Use of drip irrigation on field-grown crops has become a common practice in agricultural production in various parts of the world as it is considered being a means to achieve sustainable irrigation management practices (Cote et al., 2003). Drip fertigation is an alternative, which improves water and nutrient use efficiency and crop production and minimizes the adverse effect of groundwater quality (Ajdary et al., 2007). It was proven that fertigation strategy is one of the factors that has significant effect on nitrogen use efficiency (Hou et al., 2007) and nitrate leaching (Cote et al., 2003; Li et al., 2004; Gardenas et al., 2005; Hanson et al., 2006).

This study shows that fertigation strategy has significant effects on seed cotton yield and nitrogen fertilizer use efficiency. The N-W fertigation strategy has the highest seed cotton yield and plant ${ }^{15} \mathrm{~N}$ recovery, but with higher potential loss of fertilizer $\mathrm{N}$ from the root zone. While the $\mathrm{W}-\mathrm{N}$ fertigation strategy tends to avoid potential loss of fertilizer $\mathrm{N}$ from the root zone, it has the lowest cotton yield and nitrogen use efficiency. Our results indicate that applying nitrogen fertilizer at the beginning of the irrigation cycle (N-W fertigation strategy) is a better management option for maximizing $\mathrm{N}$ use efficiency and crop production. Although applying the nitrogen fertilizer at the end of the irrigation cycle has the potential to minimize groundwater pollution, the effect is not substantial under the drip irrigation.

\section{Conclusions}

Field experiments were conducted to study the effect of soil salinity and nitrogen $(\mathrm{N})$ fertigation strategies on seed cotton yield, dry matter, $\mathrm{N}$ uptake, and plant and soil ${ }^{15} \mathrm{~N}$ recoveries. As soil salinity level (saturation extraction) increased from 2.5 to $6.3 \mathrm{dS} \mathrm{m}^{-1}$, seed cotton yield, dry matter, $\mathrm{N}$ uptake, and plant ${ }^{15} \mathrm{~N}$ recovery were all significantly increased, but they were reduced markedly at higher soil salinity level of $10.8 \mathrm{dS} \mathrm{m}^{-1}$. Soil ${ }^{15} \mathrm{~N}$ recovery was higher under soil salinity of $10.8 \mathrm{dS} \mathrm{m}^{-1}$ than those under soil salinity of $6.3 \mathrm{dS} \mathrm{m}^{-1}$, but was not significantly different from that under soil salinity of $2.5 \mathrm{dS} \mathrm{m}^{-1}$. The highest seed cotton yield and plant ${ }^{15} \mathrm{~N}$ recovery were observed under the $\mathrm{N}-\mathrm{W}$ fertigation strategy, but the $\mathrm{N}-\mathrm{W}$ fertigation strategy showed a higher potential loss of fertilizer $\mathrm{N}$ from the root zone. Total ${ }^{15} \mathrm{~N}$ recovery was not significantly affected by soil salinity level, $\mathrm{N}$ fertigation strategy and their interaction. These results suggested that applying nitrogen at the beginning of an irrigation cycle has an advantage of improving yield and $\mathrm{N}$ fertilizer use efficiency.

Future research is needed to try to increase the low $\mathrm{N}$ recovery due to the unaccounted fertilizer $\mathrm{N}$ in the soil-cotton system under drip irrigation. Nitrogen fertilizer recovery is typically low in irrigated cotton production because of $\mathrm{N}$ loss through denitrification. The $\mathrm{N}$ fertilizer recovery and use efficiency may be improved if effective nitrification inhibitors are applied in an irrigated cotton-growing system, particularly where substantial $\mathrm{N}$ loss is apparent. Multiple $\mathrm{N}$ applications as well as other variations in application (i.e., timing and placement) may also improve the fertilizer use efficiency.

\section{References}

Ajdary, K.L., Singh, D.K., Singh, A.K., Khanna, M., 2007. Modelling of nitrogen leaching from experimental onion field under drip fertigation. Agric. Water Manage. 89, 15-28.

Alam, S.M., 1994. Nutrient uptake by plants under stress condition. In: Pessarakli, M. (Ed.),Handbook of Plant and Crop Stress. Marcel Dekker, New York, pp. 227-243.

Albassam, B.A., 2001. Effect of nitrate nutrition on growth and nitrogen assimilation of pearl millet exposed to sodium chloride stress. Plant Nutr. 24, 1325-1335.

Allen, S.C., Jose, S., Nair, P.K.R., Brecke, B.J., Ramsey, C.L., 2004. Competition for 15Nlabeled fertilizer in a pecan (Carya illinoensis K. Koch)-cotton (Gossypium hirsutum L.) alley cropping system in the southern United States. Plant Soil 263, 151-164.

Ashraf, M., 2002. Salt tolerance of cotton: some new advances. Crit. Rev. Plant Sci. $21,1-30$.

Ayars, J.E., Phene, C.J., Hutmacher, R.B., Davis, K.R., Schoneman, R.A., Vail, S.S., Mead, R.M., 1999. Subsurface drip irrigation of row crops: a review of 15 years of research at the Water Management Research Laboratory. Agric. Water Manage. 42, 1-27.

Batchelor, C.H., Lovell, C.J., Murata, M., 1996. Simple microirrigation techniques for improving irrigation efficiency on vegetable gardens. Agric. Water Manage. 32 37-48. 
Chen, D.L., Freney, J.R., Mosier, A.R., Chalk, P.M., 1994. Reducing denitrification loss with nitrification inhibitors following presowing applications of urea to a cotton field. Aust. J. Exp. Agric. 34, 75-83.

Chua, T.T., Bronson, K.F., Booker, J.D., Keeling,J.W., Mosier, A.R., Bordovsky, J.P., Lascano, R.J., Green, C.J., Segarra, E., 2003. In-season nitrogen status sensing in irrigated cotton. I. Yields and nitrogen-15 recovery. Soil Sci. Soc. Am. J. 67, 1428-1438.

Cote, C.M., Bristow, K.L., Charlesworth, P.B., Cook, F.J., Thorburn, P.J., 2003. Analysis of soil wetting and solute transport in subsurface trickle irrigation. Irrig. Sci. 22, 143-156.

El-Gharib, E.A., Kadry, W., 1983. Effect of potassium on tolerance of cotton plants to salinity of irrigation water. Ann. Agric. Sci. Moshtohor. 20, 27-34.

Feigin, A., Letey, J., Jarrell, W.M., 1982. Nitrogen utilization efficiency by drip irrigated celery receiving preplant or water applied N fertilizer. Agron. J. 74, 978-983.

Flores, P., Carvajal, M., Cerda, A., Martinez, V., 2001. Salinity and ammonium/nitrate interactions on tomato plant development, nutrition, and metabolites. Plant Nutr. 24, 1561-1573.

Freney, J.R., Simpson, J.R., Denmead, O.T., Muirhead, W.A., Leuning, R., 1985 Transformations and transfers of nitrogen after irrigating a cracking clay soil with a urea solution. Aust. J. Agric. Res. 36, 685-694.

Freney, J.R., Chen, D.L., Mosier, A.R., Rochester, I.J., Constable, G.A., Chalk, P.M., 1993 Use of nitrification inhibitors to increase fertilizer nitrogen recovery and lint yield in irrigated cotton. Fert. Res. 34, 37-44.

Fritschi, F.B., Roberts, B.A., Rains, D.W., Travis, R.L., Hutmacher, R.B., 2004. Fate of nitrogen-15 applied to irrigated Acala and Pima cotton. Agron. J. 96, 646-655.

Gardenas, A.I., Hopmans, J.W., Hanson, B.R., Simunek, J., 2005. Two-dimensional modeling of nitrate leaching for various fertigation scenarios under microirrigation. Agric. Water Manage. 74, 219-242.

Gorham, J., Bridges, J., 1995. Effects of calcium on growth and leaf ion concentrations of Gossypium hirsutum grown in saline hydroponic culture. Plant Soil 176, 219-227.

Grattan, S.R., Grieve, C.M., 1999. Salinity-mineral nutrient relations in horticultural crops. Sci. Hortic. (Amsterdam) 78, 127-157.

Hanson, B.R., Simunek, J., Hopmans, J.W., 2006. Evaluation of urea-ammoniumnitrate fertigation with drip irrigation using numerical modeling. Agric. Water Manage. 86, 102-113.

Hopmans, J.W., Bristow, K.L., 2002. Current capabilities and future needs of root water and nutrient uptake modeling. Adv. Agron. 77, 103-183.

Hou, Z., Li, P., Li, B., Gong, J., Wang, Y., 2007. Effects of fertigation scheme on N uptake and $N$ use efficiency in cotton. Plant Soil 290, 115-126.

Jacoby, B., 1994. Mechanisms involved in salt tolerance by plants. In: Pessarakli, M. (Ed.), Handbook of Plant and Crop Stress. Marcel Dekker, New York, pp. 97-145.

Jafria, Z., Ahmad, R., 1994. Plant growth and ionic distribution in cotton (Gossypium hirsutum L.) under saline environment. Pak. Bot. 26, 105-114.

Karlberg, L., Frits, W.T.P.V., 2004. Exploring potentials and constraints of low-cost drip irrigation with saline water in sub-Saharan Africa. Phys. Chem. Earth 29, 1035-1042.
Karlen, D.L., Hunt, P.G., Matheny, T.A., 1996. Fertilizer 15nitrogen recovery by corn, wheat, and cotton grown with and without pre-plant tillage on Norfolk loamy sand. Crop Sci. 36, 975-981.

Leidi, E.O., Saiz, J.F., 1997. Is salinity tolerance related to Na accumulation in upland cotton (Gossypium hirsutum) seedlings? Plant Soil 190, 67-75.

Li, J., Zhang, J., Rao, M., 2004. Wetting patterns and N distributions as affected by fertigation schemes from a surface point source. Agric. Water Manage. 67, 89104.

Mailhol, J.C., Ruelle, P., Nemeth, I., 2001. Impact of fertilization practices on nitrogen leaching under irrigation. Irrig. Sci. 20, 139-147.

Narda, N.K., Chawla, J.K., 2002. A simple nitrate sub-model for trickle fertigated potatoes. Irrig. Drain. 51, 361-371.

Papadopoulos, I., 1985. Constant feeding of field-grown tomatoes irrigated with sulphate water. Plant Soil 88, 231-236.

Pessarakli, M., 1995. Physiological response of cotton (Gossypium hirsutum L.) to salt stress. In: Pessarakli, M. (Ed.), Handbook of Crop Plants. Marcel Dekker, New York, pp. 679-693.

Powell, J.M., Kelling, K.A., Munoz, G.R., Cusick, P.R., 2005. Evaluation of dairy manure nitrogen-15 enrichment methods on short-term crop and soil nitrogen budgets. Agron. J. 97, 333-337.

Qdir, M., Shams, M., 1997. Some agronomic and physiological aspects of salt tolerance in cotton (Gossypium hirsutum L.). Agron. Crop Sci. 179, 101-106.

Raun, W.R., Johnson, G.V., 1999. Improving nitrogen use efficiency for cereal production. Agron. J. 91, 357-363.

Rochester, I.J., Constable, G.A., MacLeod, D.A., 1993. Cycling of fertilizer and cotton crop residue nitrogen. Aust. J. Soil Res. 31, 597-609.

Rochester, I.J., Constable, G.A., Saffigna, P.G., 1994. Etridiazole may conserve applied nitrogen and increase yield of irrigated cotton. Aust. J. Soil Res. 32, 1287-1300.

Sammis, T.W., 1980. Comparison of sprinkler, trickle, subsurface and furrow irrigation methods for row crops. Agron. J. 72, 701-704.

Shen, D., Shen, Q., Liang, Y., Liu, Y., 1994. Effect of nitrogen on the growth and photosynthetic activity of salt-stressed barley. Plant Nutr. 17, 787-799.

Soliman, M.S., Shalabi, H.G., Campbell, W.F., 1994. Interaction of salinity, nitrogen, and phosphorus fertilization on wheat. Plant Nutr. 17, 1163-1173.

Somma, F., Clausnitzer, V., Hopmans, J.W., 1998. Modeling of transient threedimensional soil water and solute transport with root growth and water and nutrient uptake. Plant Soil 202, 281-293.

Thompson, T.L., Doerge, T.A., Godin, R.E., 2000. Nitrogen and water interactions in subsurface drip-irrigated cauliflower. II. Agro-nomic, economic, and environmental outcomes. Soil Sci. Soc. Am. J. 64, 412-418.

Torbert, H.A., Reeves, D.W., 1994. Fertilizer nitrogen requirements for cotton production as affected by tillage and traffic. Soil Sci. Soc. Am. J. 58, 14161423.

Wang, C., Isoda, A., Wang, P., 2004. Growth and yield performance of some cotton cultivars in Xinjiang, China, an arid area with short growing period. J. Agron. Crop Sci. 190, 177-183. 